Левчук О. В., канд. екон. наук, доцент

(0000-0002-2827-2134)

Центр воєнно-стратегічних досліджень Національного університету оборони України імені Івана Черняховського, Київ

\title{
Фінансове забезпечення Збройних Сил України: тенденції та основні шляхи реформування
}

Резюме. Досліджено механізм та особливості фінансового забезпечення Збройних сил України на сучасному етапі. Проаналізовано перспективи здійснення оборонних видатків. Надано пропозиції до більш раціонального використання наявних фінансових ресурсів, а також акцентовано увагу на необхідності збільшення обсягів фінансування Збройних Сил України для забезпечення їх перспективного розвитку та зміцнення обороноздатності нашої держави.

Ключові слова: фінансування; оборонні видатки; воєнно-економічна складова системи підготовки держави до оборони; фінансове забезпечення потреб Збройних Сил України; оборонний бюджет країни; оборонна економіка; система підготовки держави до оборони; озброєння та військова техніка.

Постановка проблеми. В умовах розвитку української державності особливо гостро постає питання забезпечення безпеки i оборони України як суверенної, незалежної держави, яка стала на шлях формування демократичного державного устрою i $\epsilon$ активним учасником процесів євроатлантичної інтеграції. До того ж Збройні Сили України та інші елементи сектору безпеки i оборони відіграють важливу роль гаранта результативної реалізації як зовнішньополітичних цілей держави, так i внутрішньодержавних реформ державного управління. Ефективна організація i функціонування Збройних Сил (3С) та інших військових формувань як основних суб'єктів забезпечення національної безпеки і оборони є одним 3 основоположних факторів дієвого механізму державного управління, та залежить від низки різноманітних за своїм характером чинників. Основними 3 них $\epsilon$ воєнна безпека, економічна безпека, політична стабільність, інформаційна захищеність та військова міць.

Обороноздатність ЗС України повністю залежить від рівня соціально-економічного розвитку держави. До того ж безпека країни та ii економічне зростання нерозривно пов'язані зі станом та можливостями використання економічного та військового потенціалів. Забезпечення воєнної безпеки держави неможливе без належного фінансування iï потреб, а захист країни від внутрішніх та зовнішніх загроз і захист національної економіки - без застосування воєнної сили (збройних сил). Отже постає необхідність у виокремленні такої категорії, як воєнноекономічна складова системи підготовки держави до оборони.
Воєнно-економічну складову системи підготовки держави до оборони слід розглядати як основну, базову частину загальної системи національної безпеки держави, що зумовлює актуальність дослідження особливостей фінансування ЗС України як головного суб'єкта забезпечення національної безпеки нашої країни.

На сучасному етапі розвитку держави $€$ доцільним виокремлення поняття та визначення меж дії воєнно-економічної складової системи підготовки держави до оборони. Зазначену категорію слід розглядати не в системі економічної чи воєнної безпеки, а як інтегрований елемент у складі національної безпеки. Тобто воєнно-економічна складова системи підготовки держави до оборони може бути представлена як здатність воєнної економіки підтримувати воєнну могутність країни та реалізовувати воєнно-економічний потенціал в обсягах і термінах, передбачених керівними документами держави. Воєнноекономічна складова системи підготовки держави до оборони являє собою такий стан національного господарства України, за якого забезпечується достатній розвиток i збереження науково-виробничого потенціалу воєнної економіки, що забезпечує матеріально-технічне оснащення 3С.

Аналіз останніх досліджень. Питання фінансового забезпечення розвитку ЗС України висвітлені у працях таких науковців, як В. Горбулін, Б. Демідов, Ю. Мєдвєдєв, I. Марко, В. Мунтіян, А. Павленко, I. Семеніхін [8, 11-14]. Утім, питання раціонального розподілу бюджетних коштів для фінансування життедіяльності 
ЗС України все ще потребує більш детального вивчення.

Метою дослідження $\epsilon$ розкриття сутності і значення фінансового забезпечення армії та визначення найбільш ефективних способів розподілу оборонних витрат, що вкрай важливо в умовах ефективного використання внутрішніх джерел та обмеженості ресурсів.

Виклад основного матеріалу. Збройна агресія Російської Федерації проти України стала довгостроковим чинником впливу на українську політичну, економічну, військову та соціальну реальність. Основою фінансової складової системи готовності держави до оборони $є$ відповідність між сучасним етапом розвитку країни i характером та особливостями ведення війни у кожному конкретному випадку.

Фінансова готовність ЗС визначається також здатністю держави забезпечити відповідними ресурсами процес своєчасної організації економіки країни та мобілізаційного розгортання військ. Передвоєнна ситуація, тим більше особливий період, характеризується тим, що потреби в усіх видах ресурсів, як правило, перевищують існуючі можливості держави. Отже виникає невідповідність між потрібним та реальним рівнем фінансового забезпечення ЗС України під час виконання завдань 3 протидії гібридній війні.

Така невідповідність зумовлена, в основному, наявними недоліками забезпечення балансу між виконанням завдань українським військом і наявними ресурсами, зокрема фінансовими, на ведення операцій та утримання 3С України.

Важливою складовою забезпечення
мобілізаційного розгортання військ є
відновлення непорушних запасів до початку
мобілізації та відбиття збройної агресії.

Як відомо, фінансування ЗС України, тобто задоволення їх потреб, забезпечення життедіяльності, підготовка, утримання та розвиток здійснюються за рахунок коштів Державного бюджету. Витрати на утримання та розвиток ЗС здійснюються відповідно до затверджених кошторисів Міністерства оборони, які $\epsilon$ складовою Державного бюджету України.

Частина коштів витрачається Міністерством оборони на придбання озброєння, техніки, військового майна, продовольства, що спрямовуються до ЗС 3 різних галузей національної економіки. У цьому випадку розрахунки здійснюють відповідні департаменти Міністерства оборони через Департамент фінансів. Деякі види майна i продовольства, озброєння i військової техніки (ОВТ) замовляються і оплачуються відповідними управліннями та службами видів ЗС України через їх фінансово-економічні управління.

Озброєння, майно і продовольство, заготовлені та оплачені в центрі або у видах Збройних Сил України, відпускається військам відповідними управліннями та службами забезпечення в натуральному вигляді (безоплатно), військові частини в цьому випадку грошових розрахунків за отримане майно не здійснюють. Тобто, одним із видів забезпечення потреб військ $\epsilon$ постачання озброєння, техніки і майна в натуральному вигляді.

Інша частина коштів за кошторисом Міністерства оборони надається у розпорядження командирів військових частин на витрати, пов'язані 3 бойовою i гуманітарною підготовкою та утриманням особового складу, 3 експлуатацією та ремонтом озброєння і військової техніки. Військовим частинам кошти надаються на виплату грошового забезпечення і заробітної плати особовому складу, оплату послуг, а також на придбання майна i матеріалів, заготівля яких у централізованому порядку неможлива або недоцільна. Отже, ще одним видом забезпечення потреб військових частин $\epsilon$ надання їм коштів, виділених відповідно до затверджених лімітів у кошторисі Міністерства оборони України. Проте витрати коштів, що здійснюються безпосередньо у військових частинах, $\epsilon$ частиною бюджетних асигнувань, спрямованих на утримання $3 \mathrm{C}$.

Відповідно до вимог Бюджетного кодексу України Міністерство фінансів відповідає за складання проєкту Закону про Державний бюджет України та визначає основні організаційно-методичні засади бюджетного планування [1]. Позиція Міністерства фінансів 3 року в рік була незмінною: чим менша чисельність особового складу, тим менше видатків необхідно спрямовувати на задоволення потреб ЗС. Це призвело до того, що частка коштів, спрямованих на утримання особового складу, сягала 80 і більше відсотків загального обсягу фінансового ресурсу. Відповідно, структура бюджету Міністерства оборони $€$ значно викривленою, оскільки після виплати грошового забезпечення коштів на ремонт, модернізацію, розвиток і закупівлю озброєння 
та військової техніки фактично не залишається.

У 2003-2013 роках Міністерство оборони фінансувалось за залишковим принципом, в мінімальних обсягах - менше $1 \%$ валового внутрішнього продукту (ВВП). Унаслідок хронічного ресурсного голоду в ЗС розпочались руйнівні процеси. ВВП зростав, а видатки Державного бюджету на потреби оборони, починаючи з 2003 року невпинно зменшувались. Динаміка фінансового забезпечення Міністерства оборони України 2004 - 2013 рр. наведена на рис. 1.

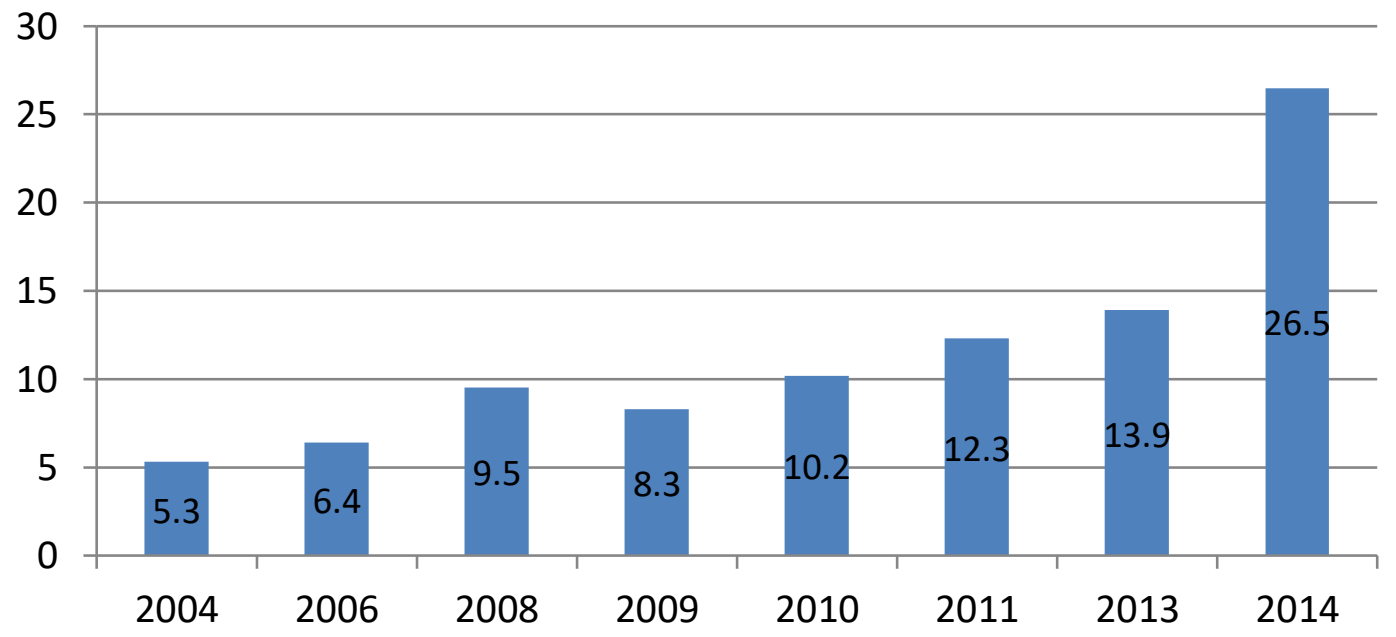

Рис. 1. Фінансове забезпечення Міністерства оборони у 2004 - 2013 рр., млрд грн*

Примімка. Узагальнено автором на основі аналізу статистичної звітності [2, 4].

Тільки 32014 року, із виникненням загрози незалежності та недоторканості України, уряд визнав реальний стан боєздатності 3С. Так, у 2015-2016 роках суттєво збільшено фінансування Збройних Сил до необхідних 2,5\% ВВП. Уже наприкінці 2014 року ця сума становила 49,1 млрд грн, а у 2016 - 58,1 млрд грн (табл. 1). Якщо порівнювати цей обсяг фінансування 32009 р., то можна побачити, що сума збільшилась майже в 4,2 рази.

Утім, якщо провести аналітичне осмислення курсу національної валюти до долара, то можна сказати, що обсяг коштів, виділених на фінансування потреб Міністерства оборони 2015-2016 pp. порівняно з 2014 роком, майже не змінився.

Фінансування потреб Збройних Сил України у 2013 - 2017 рр., млрд грн*

\begin{tabular}{|c|c|c|c|c|c|c|}
\hline \multirow{2}{*}{$\begin{array}{c}\text { № } \\
\text { П/II }\end{array}$} & \multirow{2}{*}{ Показник } & \multicolumn{5}{|c|}{ Роки } \\
\hline & & 2013 & 2014 & 2015 & 2016 & 2017 \\
\hline 1 & Бюджетний запит МО України & 23,8 & 25,6 & 48,3 & 86,9 & 109,9 \\
\hline 2 & $\begin{array}{lccc}\text { Передбачено } & \text { Законом } & \text { України } & \text { про } \\
\text { Державний бюджет України (зі змінами) } & \end{array}$ & 15,3 & 15,1 & 45,8 & 59,4 & 68,8 \\
\hline 3 & Фактично використано з них: & 13,9 & 26,5 & 49,1 & 58,1 & 68,8 \\
\hline 4 & Розвиток озброєння і військової техніки & 1,05 & 3,9 & 10,2 & 9,3 & 15,2 \\
\hline 5 & Підготовка Збройних Сил України & 1,6 & 0,8 & 2,0 & 2,7 & 2,6 \\
\hline 6 & Утримання Збройних Сил України & 11,2 & 21,8 & 36,8 & 46,1 & 51,1 \\
\hline 7 & \% до ВВП від фактично використаного & 0,96 & 1,69 & 2,65 & 2,57 & 2,31 \\
\hline
\end{tabular}

Примітка. Узагальнено автором на основі матеріалів науково-практичної конференції [9].

Довідка. Державним бюджетом України було передбачено такий обсяг видатків Міністерства оборони:

на 2014 рік - 26510,00 млн грн / 2231,5 млн USD (офіційний курс 1 USD = 11,88 грн);

на 2015 рік - 49084,3 млн грн / 2257,8 млн USD (офіційний курс 1 USD = 21,74 грн);

На 2016 рік - 58099,2 млн грн / 2410,7 млн USD (офіційний курс 1 USD = 24,1 грн).

Упродовж 2009 - 2013 рр. ситуація для 3С України була вкрай несприятливою. На національну оборону виділялось менше 1 \% ВВП, що суттєво обмежує і нині можливість повного виконання покладених на ЗС завдань.

Ученими неодноразово доведено, що у разі, коли на потреби ЗС виділяється менше $1 \%$ ВВП, фактично відбувається їх руйнація, а не розвиток. 
Аналіз розподілу ресурсів за видатками засвідчує, що основний їх обсяг зосереджений на утриманні ЗС України, тобто має місце так званий бюджет “проїдання” (табл. 2).

Таблиця 2

Розподіл видатків Міністерства оборони України у 2009 - 2017 рр., млн грн"

\begin{tabular}{|c|c|c|c|c|c|c|c|c|c|}
\hline \multirow[b]{2}{*}{ Показник } & \multicolumn{9}{|c|}{ Роки } \\
\hline & 2009 & 2010 & 2011 & 2012 & 2013 & 2014 & 2015 & 2016 & 2017 \\
\hline $\begin{array}{l}\text { Бюджетний } \\
\text { запит } \\
\text { МО України, } \\
\text { млн грн }\end{array}$ & 31976,7 & 19853,4 & 14289,8 & 17416,5 & 23836,6 & 25550,1 & 48245,6 & 86951,9 & 109946,2 \\
\hline $\begin{array}{l}\text { Передбачено } \\
\text { Законом України } \\
\text { про Державний } \\
\text { бюджет }\end{array}$ & 11650,1 & 11335,1 & 13668,8 & 16387,5 & 15315,1 & 15151,0 & 45827,3 & 59427,3 & 68819,6 \\
\hline \multirow{2}{*}{ Розвиток ОВТ } & 592,2 & 648,9 & 817,3 & 1450,8 & 1057,5 & 3892,6 & 10223,9 & 9291,9 & 15152,7 \\
\hline & $7,1 \%$ & $6,3 \%$ & $6,6 \%$ & $10,3 \%$ & $7,6 \%$ & $14,7 \%$ & $20,8 \%$ & $16,0 \%$ & $22,0 \%$ \\
\hline \multirow{2}{*}{$\begin{array}{c}\text { Підготовка 3С } \\
\text { України }\end{array}$} & 235,4 & 429,6 & 461,5 & 702,9 & 1642,0 & 823,3 & 2003,3 & 2680,4 & 2614,0 \\
\hline & $2,8 \%$ & $4,2 \%$ & $3,8 \%$ & $5,0 \%$ & $11,8 \%$ & $3,1 \%$ & $4,1 \%$ & $4,6 \%$ & $3,8 \%$ \\
\hline \multirow{2}{*}{$\begin{array}{c}\text { Утримання 3С } \\
\text { України }\end{array}$} & 7506,8 & 9163,7 & 11016,3 & 11887,5 & 11231,9 & 21794,1 & 36857,1 & 46126,9 & 51092,1 \\
\hline & $90,1 \%$ & $89,5 \%$ & $89,6 \%$ & $84,7 \%$ & $80,6 \%$ & $82,2 \%$ & $75,1 \%$ & $79,4 \%$ & $74,2 \%$ \\
\hline $\begin{array}{c}\text { Відсоток до } \\
\text { ВВП від факт. }\end{array}$ & $0,91 \%$ & $0,95 \%$ & $0,94 \%$ & $1,00 \%$ & $0,96 \%$ & $1,69 \%$ & $2,65 \%$ & $2,57 \%$ & $2,31 \%$ \\
\hline
\end{tabular}

Примітка. Узагальнено автором на основі статистичної інформації [8-10].

Отже, на утримання ЗС України впродовж останнього десятиріччя виділяється понад $80 \%$ загального бюджету Міністерства оборони. У 2009 році цей показник становив $90,1 \%$, і був найвищим за всю історію незалежності України. У 2010 році видатки на утримання 3С України становили $89,5 \%$. Такі показники можна виправдати світовою фінансовою кризою, що припала саме на цей період.

Видатки на розвиток озброєння та військової техніки становили від $6,3 \%$ до $10,6 \%$. Подібна ситуація склалася і з видатками на підготовку ЗС України: найнижчі показники $2,8 \%$ у 2009 році, $4,2 \%-2010$ рік, $5 \%-2011$ рік (табл. 2). Проте, як показує світова практика, розподіл видатків на розвиток Збройних Сил має відбуватись таким чином: $40 \%$ - утримання збройних сил, $20 \%$ - підготовка збройних сил, $40 \%$ - розвиток озброєння та військової техніки.

Державний бюджет України на 2020 рік покриває лише $50 \%$ потреб, заявлених Генеральним штабом ЗС України. Зокрема, в бюджет 2020 року закладено 102 млрд грн за реальної потреби в приблизно 220 млрд грн [3].

Крім того, відповідно до Рішення РНБО України від 25 квітня 2019 року (введено в дію Указом Президента України від 25 квітня 2019 року № 167/2019), видатки на потреби МО України у 2020 році мають складати не менше 211,3 млрд грн [7]. Також у квітні 2019 року РНБО затвердило Пропозиції до Бюджетної декларації на $2020-2022$ рр. за статтями, пов'язаними із забезпеченням національної безпеки і оборони України (рис. 3) [7].

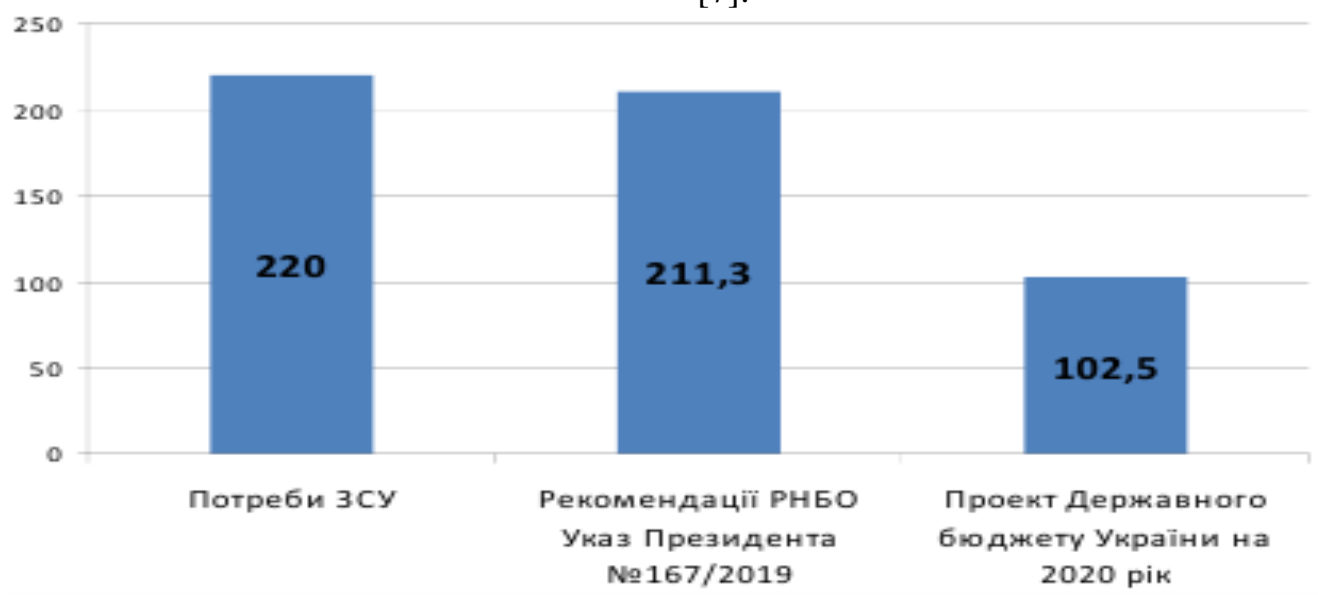

Рис. 3. Фінансування потреб Збройних Сил України у 2020 р., млрд грн

Примітка. Розраховано автором на основі офіційної статистичної інформації [2, 3]. 
Аналізуючи показники проєкту Державного бюджету України на 2020 рік, на перший погляд можна сказати, що оборонний бюджет 2020 передбачає фінансування потреб ЗС України на рівні поточного, 2019 року. Проте, якщо порівняти видатки із номінальним ВВП, то отримуємо зовсім іншу картину.

Тут слід зазначити, що валовий внутрішній продукт України враховує вартість всіх товарів і послуг, вироблених в країні за певний період. Зіставлення фізичних обсягів виробництва різних періодів 3 метою визначення їхнього реального зрушення можна забезпечити лише за умов, якщо ціни будуть незмінними. Насправді в ринковій економіці ціни 3 року в рік, як правило, змінюються: зростають або знижуються. Тому, з метою нівелювання цінового фактора, в макроекономічних розрахунках обчислюють два види ВВП: номінальний i реальний, застосовуючи при цьому два види цін: поточні і постійні.

Номінальний валовий внутрішній продукт (номінальний ВВП) - це обсяг виробництва, який вимірюється в поточних цінах, тобто в цінах, що існують на момент виробництва [12].

Реальний валовий внутрішній продукт (реальний ВВП) - це обсяг виробництва, який вимірюється в сталих (незмінних, базових) цінах, тобто на величину цього показника впливає лише зміна обсягів виробництва [12].

У 2019 р. бюджет Міністерства оборони України складає 102,5 млрд грн. Номінальний ВВП на 2019 р. становить 3977,0 млрд грн. Відповідно, витрати на потреби Міністерства оборони складають 2,58 \% від розміру номінального ВВП $[3,14]$.

Проєктом Державного бюджету на 2020 рік фінансування Міністерства оборони передбачено у розмірі 102,556 млрд грн [3]. До того ж номінальний ВВП на 2020 р. 4551,0 млрд грн. Отже, частка видатків Міністерства оборони становить 2,25\% від розміру номінального ВВП. Фактично бюджет Міністерства оборони на $0,32 \%$ менше від суми номінального ВВП, що у грошовому еквіваленті становить 14,7 млрд грн. Тобто, він навіть не виходить на рівень 2019 року, не кажучи вже про збільшення видатків на потреби ЗС (рис. 4).

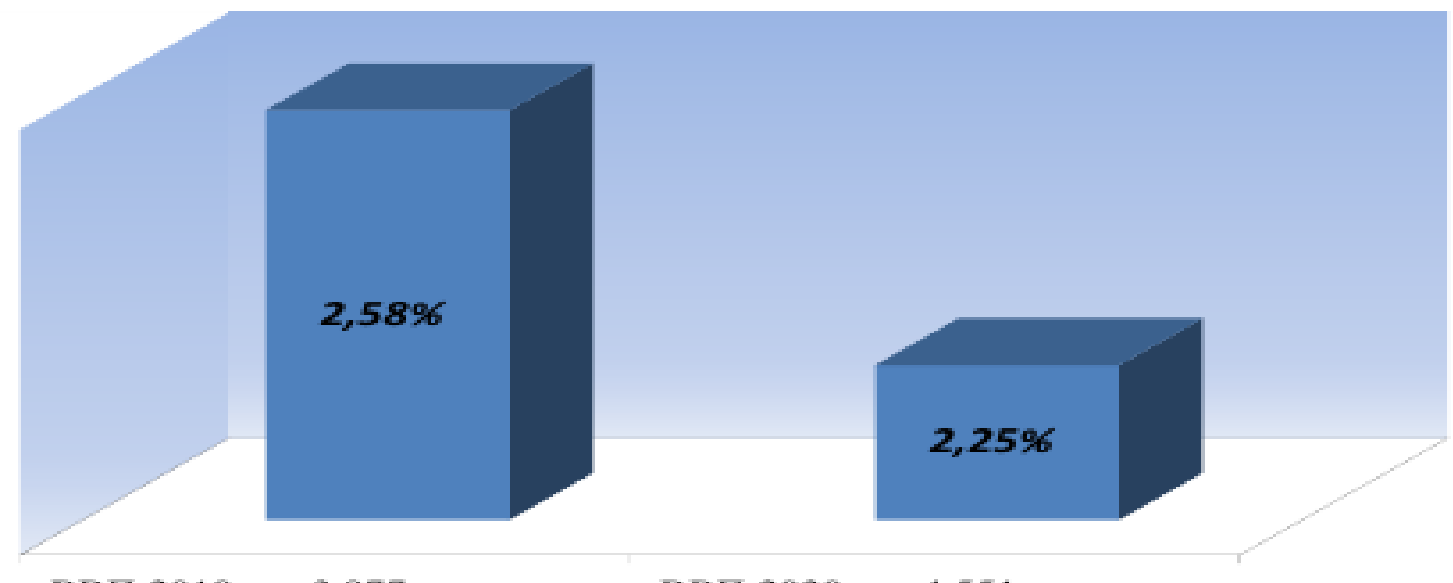

ВВП 2019 р. - 3,977 трлн. грн. ВВП 2020 р. - 4,551 трлн. грн.

Рис. 4. Відсоток від суми номінального ВВП на потреби Збройних Сил України, 2019-2020 рр.

Примітка. Розраховано автором на основі офіційної інформації [2, 3].

Слід звернути особливу увагу на те, що значна частина військового бюджету витрачається на утримання особового складу 3С України. Так, відповідно до ст. 35 Закону України "Про національну безпеку України", “... обсяг видатків на фінансування сектору безпеки і оборони має становити не менше $5 \%$ запланованого обсягу валового внутрішнього продукту, з яких не менше $3 \%$ на фінансування сил оборони" [4]. Отже, витрати на ЗС мають складати 136,5 млрд грн. Відповідно до проєкту Державного бюджету2020, 3С України вже недофінансовані майже на 34 млрд грн.
Однією із суттєвих проблем зміцнення обороноздатності вітчизняного війська $\epsilon$ недостатне фінансування та відсутність у Міністерства оборони України можливості розміщувати в необхідному обсязі замовлення на нове озброєння та військову техніку та проведення спеціалізованих НДДКР для створення перспективних розробок ОВТ. Динаміка фінансування розвитку, закупівлі, модернізації та ремонту озброєння, військової техніки, засобів та обладнання наведено на рис. 5. 


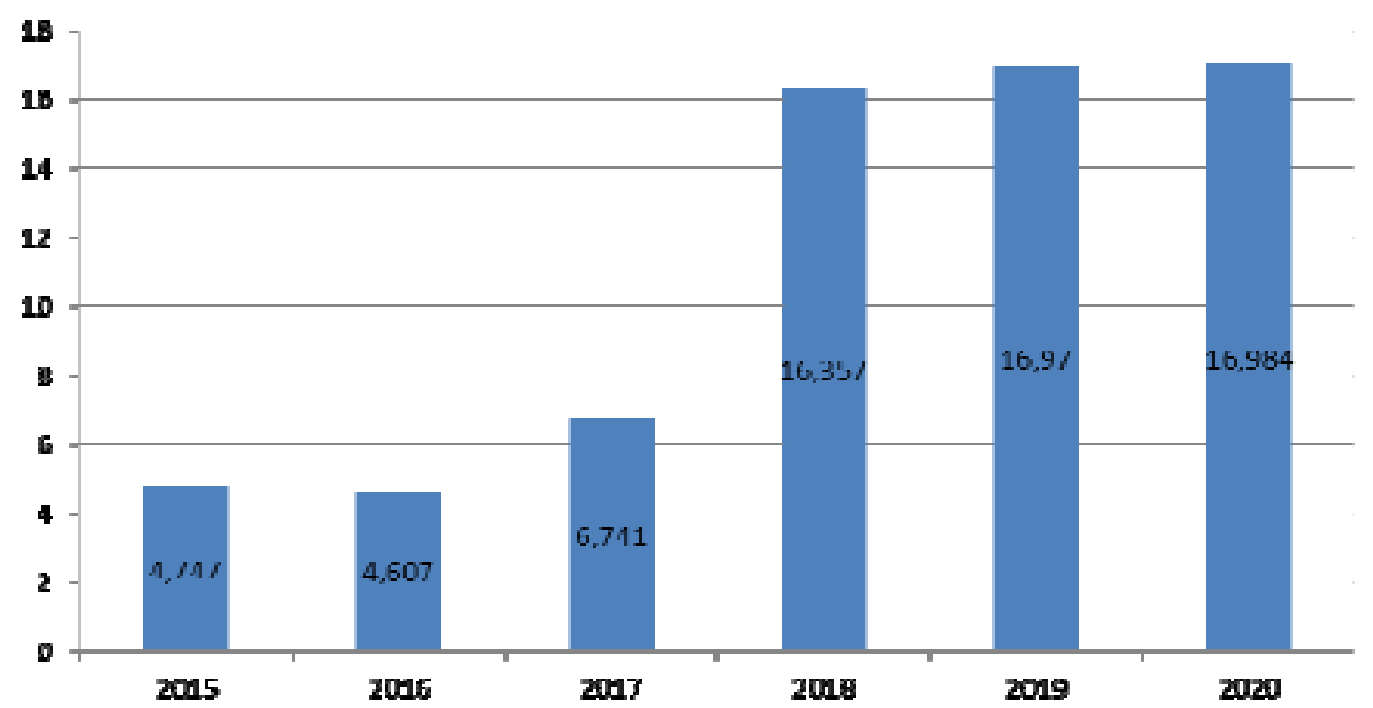

Рис. 5. Динаміка обсягів фінансування розвитку, модернізації та ремонту обладнання, військової техніки, засобів та обладнання для Збройних Сил України у 2015 - 2020 рр., млрд грн

Примітка. Узагальнено автором на основі статистичної інформації [7-9].

У 2016 році було заплановано виділити на переозброєння вітчизняного війська майже 170 млрд грн [14]. Упродовж наступних п'яти років зазначені кошти мали бути спрямовані на задоволення таких потреб:

оновлення парку літаків, вертольотів, зенітних ракетних комплексів, радіотехнічних систем;

модернізацію засобів зв'язку та радіоелектронної боротьби, артилерійської розвідки і навігації;

забезпечення військових частин безпілотними авіаційними комплексами;

забезпечення зенітно-ракетними

комплексами;

встановлення розвідувально-

спостережних охоронних систем та засобів боротьби 3 безпілотними літальними апаратами;

розроблення і виробництво наземних, повітряних та морських високоточних артилерійських та протитанкових систем, керованих авіабомб;

створення інтегрованої системи управління, збору та обробки розвідувальних відомостей;

будівництво нових кораблів і катерів.

За оцінкою Командування Повітряних Сил, існуючий парк бойових літаків 3 урахуванням продовження термінів їх служби та ресурсу, може знаходитися у складі ЗС України до 2025-2030 pp. Програмноцільовий метод планування розвитку озброєння та військової техніки передбачає, що заходи щодо заміни парку бойових літаків в Україні мають бути завчасно сплановані.
Крім того, повинні плануватися не лише фінансові ресурси, а також конкретні результати: наприклад, переозброєння однієї (двох, трьох) авіаційної ескадрильї на новий тип бойового літака, отримання нових підвищених бойових можливостей цього підрозділу (підрозділів) під час виконання завдань за призначенням.

Проте нині потрібні випереджальні у часі дії. Адже у 2025-2030 рр. може не вистачити часу та фінансового ресурсу для розв'язання такої надскладної проблеми, як заміна парку бойових літаків в Україні.

Прогноз фінансового ресурсу на заміну парку бойових літаків на період до 2025 року розраховується на підставі аналізу необхідної інформації (ВВП, видатків на потребу 3С України, розвиток ОВТ). За проведеною оцінкою визначений середній відсоток на розвиток ОВТ від планових показників видатків на ЗС України складає $13 \%$, хоча в арміях провідних країн світу цей показник становить щонайменше $30 \%$.

На підставі інформації щодо прогнозу економічного та соціального розвитку України на 2020 - 2022 роки 3 урахуванням сценарію 2, визначені прогнозні показники ВВП України, до того ж з 2018 р. та надалі закладено зростання ВВП на 3,5 \% щороку 3 урахуванням $2 \%$ ВВП на розвиток 3С України отримані фінансові показники 3 2019 до 2025 року. 3 урахуванням середнього відсотку $13 \%$ на розвиток ОВТ від видатків на 3С отримані прогнозні фінансові показники на розвиток ОВТ на період до 2025 р. (табл. 3). 
Прогноз фінансового ресурсу на заміну парку бойових літаків за роками

(30\% від видатків на розвиток ОВТ)

\begin{tabular}{|c|c|c|c|c|c|c|c|}
\hline Показники видатків & 2019 & 2020 & 2021 & 2022 & 2023 & 2024 & 2025 \\
\hline ВВП (Укрстат), \$ млн & 114899 & 118920 & 123082 & 127390 & 131849 & 136464 & 141240 \\
\hline ВВП (Укрстат), млн грн & 2527769,6 & 2616241,6 & 2707810 & 2802583 & 2900674 & 3002197 & 3107274 \\
\hline Відсоток ВВП на ЗС, \% & 2,0 & 2,0 & 2,0 & 2,0 & 2,0 & 2,0 & 2,0 \\
\hline $\begin{array}{l}\begin{array}{l}\text { Видатки на потребу } \\
\text { (план) }\end{array} \\
\text { (п) }\end{array}$ & 50555,4 & 52324,8 & 54156,2 & 56051,7 & 58013,5 & 60043,9 & 62145,5 \\
\hline $\begin{array}{l}\text { Видатки на розвиток ОВТ } \\
\text { та I*, факт, млн грн }\end{array}$ & 6572,2 & 6802,2 & 7040,3 & 7286,7 & 7541,8 & 7805,7 & 8078,9 \\
\hline $\begin{array}{l}\text { Видатки на розвиток } \\
\text { OВТ та I, факт, \$ млн }\end{array}$ & 298,74 & 309,2 & 320,0 & 331,2 & 342,8 & 354,9 & 367,2 \\
\hline $\begin{array}{l}\text { Відсоток на розвиток ОВТ } \\
\text { від планових показників } \\
\text { видатків на ЗС, } \%\end{array}$ & 13,0 & 13,0 & 13,0 & 13,0 & 13,0 & 13,0 & 13,0 \\
\hline $\begin{array}{llr}\text { Фінансовий ресурс } & \text { на } \\
\text { заміну парку літаків } & \text { за } \\
\text { роками, } 30 \%, \$ \text { млн } & \\
\end{array}$ & 89,6 & 92,8 & 96,0 & 99,4 & 102,8 & 106,4 & 110,2 \\
\hline \multicolumn{6}{|c|}{ Фінансовий ресурс на заміну парку бойових літаків, \$ млн } & \multicolumn{2}{|c|}{941,21} \\
\hline
\end{tabular}

ОВТ та I-озброєння, військова техніка та інфраструктура

Загалом оцінка варіантів заміни парку бойових літаків в Україні здійснюється за таким ітераційним алгоритмом: 1) визначення мінімальної кількості літаків, що планується закупити для заміни парку бойових літаків; 2) обрання класу бойового літака, яким планується оновити парк бойових літаків; 3) оцінка достатності фінансових ресурсів для заміни парку бойових літаків відповідно до обраного класу. У разі недостатності фінансового ресурсу необхідна заміна варіанта та обрання іншого класу літака за рахунок зменшення амбіцій в частині функціональних можливостей літака. Як було зазначено вище, в арміях провідних країн світу на розвиток ОВТ виділяється $30 \%$ від планових показників видатків на 3С. Отже, якщо приблизно $30 \%$ фінансового ресурсу від видатків на розвиток ОВТ кожного року будуть направлені на заміну парку бойових літаків, то у 2025 році прогнозується, що буде акумульовано на рахунку за відповідною статтею бюджету фінансовий ресурс, який у перерахунку складе близько 941,2 \$ млн (табл. 3).

Крім того, потреба в коштах на утримання (обслуговування, поточний, середній, капітальний ремонт) OBT номенклатури оперативного забезпечення складає 1178,5 млн грн, серед яких:

$$
11,1 \text { млн грн на техніку }
$$

радіоелектронної боротьби;

70,2 млн грн на інженерну техніку;

10,2 млн грн на техніку та озброєння радіаційного, хімічного, біологічного захисту 17,9 млн грн на топогеодезичну і навігаційну техніку.
Це дасть змогу подовжити ресурс лише $13 \%$ наявного ОВТ. До проблем підтримання боєготовності частин i підрозділів оперативного (бойового) забезпечення на належному рівні також відноситься недостатній рівень фінансування закупівель OBT. Особливо гостро стоїть питання закупівель техніки радіоелектронної боротьби i топогеодезичної техніки, яка $\epsilon$ високотехнологічною і вартісною, й на підприємствах України не виготовляється.

Водночас, для Апарату Ради національної безпеки і оборони України на 2020 рік закладені кошти за кодом програмної класифікації видатків та кредитування (КПКВК) 6501060 - нерозподілені видатки на національну безпеку і оборону - у розмірі 27,9 млрд грн. Як було повідомлено офіційно, зазначені кошти будуть розподілені РНБО між оборонними та безпековими відомствами [14]. Утім, і досі невідомо, за яким принципом буде проведено цей розподіл. Якщо говорити про бюджет 3С, то для досягнення рівня фінансування 2019 року, МО України має отримати мінімум $50 \%$ від цієї суми.

На сьогодні основними проблемними місцями ЗС України є:

забезпечення конкурентного грошового забезпечення військовослужбовців; забезпечення особового складу житлом; необхідність проведення переозброєння української армії; необхідність формування непорушних запасів;

завершення виконання програми забезпечення життєдіяльності та безпеки арсеналів, баз і складів боєприпасів. 
Військове майно непорушних запасів являє собою майно, призначене для використання в особливий період і перебуває в мирний час на довгостроковому зберіганні у військових частинах [9]. На сьогодні для формування та оновлення непорушних запасів ЗС України потрібно майже 36 млрд грн.

Завершення виконання програми забезпечення життєдіяльності та безпеки арсеналів, баз і складів боєприпасів потребує фінансування у розмірі приблизно 100 млрд грн. Для забезпечення особового складу ЗС України житлом, зокрема, будівництва модульних містечок, необхідно також приблизно 100 млрд грн.

Основними проблемними місцями у забезпеченні ЗС України озброєнням та військовою технікою $є$ протиповітряна оборона, бойова авіація та флот. Так, справність авіації на сьогодні становить 2530 \%. Наразі Україна ще не виробляс ракетних комплексів, здатних забезпечити повноцінну протиповітряну оборону. Із визначених Генеральним штабом ЗС України потреб на 2020 рік у розмірі приблизно 220 млрд грн на розвиток озброєння та військової техніки необхідно виділяти щонайменше $40 \%$, тобто 80 - 90 млрд грн. До того ж слід зазначити, що, з огляду на масштаб проблем, які існують в армії через багаторічне фінансування Міністерства оборони України за залишковим принципом, рівень оборонних витрат ще не один рік необхідно буде збільшувати.

Нині, як ніколи, зростає актуальність питань фінансового забезпечення потреб ЗС України, адже вони $є$ одним із найважливіших національних пріоритетів, гарантом державної незалежності України, умовою іiі сталого економічного розвитку i, відповідно, зростання добробуту громадян.

Недостатній рівень фінансування армії в період іiі реформування поставив питання необхідності якісних змін у підходах до планування, розподілу, витрачання та обліку фінансових ресурсів, пошуку внутрішніх джерел фінансування військ. Забезпечення раціонального використання оборонних коштів у сучасних економічних умовах залежить від професійності, здатності працювати в нових умовах, потребує вмілої діяльності органів управління і особового складу Збройних Сил України.

Істотним недоліком фінансового становища $3 \mathrm{C}$ України $є$ недосконалість розподілу оборонних видатків. Це безпосередньо впливає на реалізацію Державних програм реформування і розвитку української армії. Успішне вирішення завдань, покладених на ЗС України, неодмінно залежить від правильного визначення та обгрунтування потреб і організації їх фінансування. Крім того, видатки на оборону $\epsilon$ важливою складовою державних фінансів.

Такі видатки, по-перше, забезпечують умови виживання держави; по-друге, розвиток вітчизняних науково-дослідних i дослідноконструкторських робіт; по-трете, підготовку висококваліфікованих спеціалістів найвищого рівня; по-четверте, створення робочих місць; по-п'яте - забезпечення української армії сучасним озброєнням та військовою технікою власного виробництва; по-шосте - експорт озброєнь, який дає можливість розширити потенціал держави та наповнити Державний бюджет країни додатковими коштами; посьоме, задоволення соціальних потреб особового складу та посилення мотивації до служби у лавах ЗС України; по-восьме співробітництво у військово-політичній та військово-технічній сферах.

Оборонний бюджет є загальним обсягом грошових коштів, які виділяються державою для фінансування конкретних потреб збройних сил упродовж даного фінансового року.

Боєздатність Збройних Сил України, моральний дух особового складу та його соціальний захист значною мірою залежать від реалізації механізму фінансового забезпечення армії. Крім того, для фінансування відповідних програм необхідно відпрацювати i законодавчо визначити напрями мобілізації ресурсів. Отже, фінансовий механізм в цілому - це принципова схема практичного використання воєнних фінансів в економіці збройних сил, їх впливу на воєнно-економічну складову системи підготовки держави до оборони.

Здійснивши аналітичне осмислення співвідношення обсягу ВВП до оборонних витрат України впродовж останніх років можна констатувати, що вимоги Законів України "Про Збройні Сили України" та "Про національну безпеку України" не виконувались жодного року. У середньому цей показник становив $1,5-1,55 \%$, тобто вдвічі менше від суми, визначеної в Законі України "Про національну безпеку України" (3\% від валового внутрішнього продукту). Унаслідок таких непродуманих дій відбувся закономірний занепад воєнно-економічного потенціалу 3С.

Воєнно-економічний потенціал - це частка економічного потенціалу держави, що 
виражає воєнно-економічні можливості держави, які можуть бути спрямовані на задоволення матеріальних потреб та на комплектування збройних сил для ведення війни. Математично він має вигляд:

$$
B E \Pi=K_{6} \cdot E \Pi,
$$

де ВЕП - воєнно-економічний потенціал;

$\mathrm{K}_{\mathrm{B}}-$ коефіцієнт використання економічного потенціалу ( $\left.0<K_{B}<1\right)$;

ЕП - економічний потенціал.

Оборонні витрати забезпечують умови для розвитку i процвітання держави. Вони сприяють розвитку вітчизняних науководослідних робіт, збереженню високого промислового потенціалу оборонної галузі, забезпечують підготовку висококваліфікованих фахівців різноманітної спеціалізації, створюють нові робочі місця.

Розподіл обмежених ресурсів, без сумніву, $\epsilon$ одним 3 найважчих рішень i найскладніших функцій як виконавчої, так i законодавчої гілок влади. Це означає, що існує проблема розподілу цих ресурсів - головним чином фінансів та опосередковано - людських і матеріальних ресурсів та інфраструктури, 3 метою виконання пріоритетів та задоволення основних потреб.

Попри значні досягнення у формуванні багатьох важливих складових воєнних фінансів, наявна система бюджетного прогнозування і планування характеризується комплексом фундаментальних проблем, основними 3 яких $\epsilon$, по-перше, відірваність бюджетного прогнозування від загальнодержавного планування. Водночас відсутній чіткий зв'язок між державним та оборонним бюджетним плануванням. Наслідком цього $є$ формування бюджету воєнних фінансів не за принципом реальних потреб, а за залишковим принципом, тобто безвідносно до пріоритетів Державної програми розвитку ЗС України. По-друге, має місце прецедент, коли бюджетне прогнозування фактично підпорядковується короткостроковому бюджетному плануванню, a не навпаки. Фактично як бюджетне прогнозування, так i фінансове планування мають декларативний характер, оскільки плановий прогноз не є реальним орієнтиром $\mathrm{i}$ не збігається 3 реаліями бюджетного фінансування. По-третє, доволі часто програмно-цільовий метод формування й розподілу воєнних фінансів базується не на стратегічних завданнях, а супроводжується некоректно обраною системою показників.
За таких умов порушується глибинна сутність оборонної стратегії держави, іï здатність визначати широкий спектр назрілих завдань i цілей. Зрозуміло, що наслідком подібних планових деформацій $є$ порушення фінансової політики. Вони реально ускладнюють виконання завдань досягнення необхідної обороноздатності країни найбільш фінансово раціональним шляхом. 3 усіх статей державного бюджету саме витрати на оборону становлять найбільший суспільний та міжнародний інтерес.

Оборонна структура має бути ефективною, тобто досягати бажаного результату. Водночас вона має економною, тобто здатною досягати потрібного результату без перевитрат, мінімізуючи витрати енергії та коштів. На сьогодні основним викликом для сучасної оборонної структури є забезпечення нового балансу між завданнями збройних сил i наявними фінансовими ресурсами. В умовах обмежених витрат на оборону та сучасних змін у стратегічних пріоритетах зростає потреба в отриманні максимального ефекту від тих коштів, які виділяються на оборону.

Реальні та науково обгрунтовані напрями зниження витрат на оборону можна встановити лише на основі глибокого наукового аналізу всього спектра умов та факторів, котрі впливають на бойові можливості збройних сил. Водночас фінансова ситуація перманентно (з року в рік) значно ускладнюється. На оборонний бюджет накладається відчутне фінансове навантаження у зв'язку 3 модернізацією 3С України, поступовим переходом на стандарти НАТО, оновленням озброєння та військової техніки, створенням нових зразків OBT.

Для цього необхідно глибоко опрацювати ймовірні сценарії воєнних конфліктів i на основі цього визначити мінімальні вимоги до рівня розвитку збройних сил, оптимальний розподіл бойових завдань (зокрема за потрібними витратами), розробити програми і плани розвитку видів збройних сил i систем озброєння, підвищити якість та вдосконалити способи його бойового застосування. Вдале розв'язання цих проблем визначається передусім розвитком i співвідношенням відповідних галузей воєнної науки. Бажання економити на цьому призводить до протилежного результату.

У ЗС України бюджетне фінансування визначається обсягом завдань, які вирішують ЗС України. До того ж найважливіші показники - ефективність та вартість. Перший 
визначає можливий результат діяльності системи, другий - сукупність витрат на іiі створення й утримання. Підходи до дослідження й оцінювання систем 3 використанням цих показників можуть бути різними.

Перший. Ефективність системи (W) має бути не менша за потрібну $\left(W_{\text {nотр }}\right)$, вартість (C) - мінімальна (2):

$$
W \geq W_{\text {nomp }}, C \leq C_{\min } .
$$

Другий. Вартість - не більша заданої (потрібної або виділеної), ефективність на цім може бути вищою $\left(W_{\max }\right)(3)$ :

$$
W=W_{\max }, C \leq C_{\max } .
$$

Раціональним шляхом підготовки 3С України може бути варіант, у якому враховуються потрібна спроможність 3С України та мінімальні затрати на піi забезпечення.

На першому етапі проводиться аналіз умов виникнення (з урахуванням критичних ситуацій) та цілей можливих воєн, розробляються їх сценарії. На основі аналізу визначаються завдання для видів збройних сил та систем озброєння. Основний зміст цього етапу - моделювання бойових дій, а результат - визначення потрібної спроможності збройних сил та їх складових. Зменшення витрат на оборону можливе за рахунок обгрунтування цілей і завдань війни, оптимальний розподіл витрат між видами збройних сил та системами озброєння, враховуючи можливості їх взаємодії.

На другому етапі формуються варіанти вдосконалення видів збройних сил, які забезпечують досягнення визначених цілей, враховуючи вдосконалення озброєння та способів його бойового застосування. Перелік варіантів у такому разі має бути достатнім. Основний зміст другого етапу - моделювання бойових дій на рівні видів збройних сил i систем озброєння.

На третьому етапі здійснюється оцінювання потрібних витрат на оборону за різними варіантами розвитку збройних сил, визначення напряму, який потребує найменших витрат як на рівні складових, так і загалом.

На четвертому етапі відбувається розроблення програм розвитку видів збройних сил загалом, визначаються всі основні умови та необхідні заходи, а також здійснюється перевірка цих програм за можливими обмеженнями.
Важливе місце в обгрунтуванні шляхів розвитку збройних сил і потрібних для цього витрат посідають питання формування i вибору варіантів видів збройних сил та систем озброєння. Це на часі ще й тому, що переважна більшість сучасних держав давно відмовилась від політики “ручного" та кон'юнктурного управління бюджетом, сформувавши ефективну систему вироблення пріоритетів використання бюджетних коштів, в основі якої лежать високопрофесійне середньострокове бюджетне прогнозування та цільове середньострокове бюджетне планування, тісно інтегроване в систему наявних воєнних фінансів.

Оборонний бюджет має визначатися 3 урахуванням рівня безпеки і загроз, які стоять перед державою. Проте насправді обмеженість державних ресурсів призводить до того, що витрати на оборону визначаються, зважаючи на наявні ресурси та рівні інфляції, а не на реальний рівень загроз безпеці держави.

Рівень, на якому нині перебувають ЗС України, не є випадковим. Для того, щоб змінити ситуацію в майбутньому і не лише найближчому, а й у довгостроковій перспективі, необхідно діяти вже сьогодні. Світова практика показує, що видатки мають розподілятися таким чином: $40 \%$ - утримання збройних сил, $20 \%$ - підготовка військ, $40 \%$ - розвиток озброєння та військової техніки.

Складання раціонального оборонного бюджету як складової державного бюджету неможливе без відновлення вітчизняного виробництва на основі оновлення технології та залучення до нього вивільнених працівників. Основними в цьому процесі $\epsilon$ поглиблення фінансової стабілізації та зростання прибутків, які можливі лише на основі реального за своїми доходами бюджету. Для планування оборонного бюджету важливо рішуче ставити питання про економічну стабілізацію вітчизняного виробництва та його подальший розвиток, зміцнення фінансів низової ланки підприємств та організацій, суб'єктів економічної діяльності. До розширеного відтворення виробництва відкриває дорогу зниження податкового тиску й запровадження нової політики амортизації. Реалізація цих завдань дасть змогу перейти від формальних атрибутів державності. Зокрема, i у ЗС України, до реального та якісного їх наповнення. 
Висновки. Підсумовуючи викладене, можна сказати, що на сьогодні у питаннях фінансового забезпечення ЗС України $є$ такі проблемні моменти:

$$
\text { 1. Упродовж } 2003-2014 \mathrm{pp} \text {. }
$$

Міністерство оборони фінансувалось за залишковим принципом та в мінімальному обсязі - менше 1 \% від валового внутрішнього продукту. Унаслідок цього хронічного ресурсного голоду в ЗС України розпочались руйнівні процеси;

2. Як показує світова практика, розподіл видатків на розвиток ЗС має відбуватись таким чином: $40 \%$ - утримання збройних сил, $20 \%$ - підготовка військ, $40 \%$ - розвиток озброєння та військової техніки. В українських реаліях левова доля оборонних видатків спрямовується на утримання особового складу - приблизно $75 \%$, на підготовку ЗС виділяється від 3,8 до 4,3\%, та $22 \%$ - на розвиток озброєння і військової техніки. Для країни, що фактично перебуває шостий рік у стані війни, такий розподіл бюджетних коштів є вкрай неефективним;

3. Частка видатків Міністерства оборони України становить 2,25\% від розміру ВВП. Фактично бюджет МО України на 0,32\% менше від суми номінального ВВП, що у грошовому еквіваленті становить 14,7 млрд грн. Як бачимо, він навіть не виходить на рівень 2019 року, не кажучи вже про збільшення видатків на потреби армії. До того ж відповідно до ст. 35 Закону України "Про національну безпеку України", рівень оборонних витрат не може бути нижчим $3 \%$ від ВВП.

Слід зауважити, що оборонний бюджет не можна розробляти без стратегічного планування та розуміння сутності воєнної стратегії. Під час ухвалення рішень, які безпосередньо впливають на обороноздатність армії, потрібно вимагати професійної оцінки ефективності розподілу та використання ресурсів, а також відповідної інформаційної підтримки конкретних цілей і завдань, на які спрямовуються оборонні видатки. Це дасть змогу своєчасно вживати заходи, спрямовані на досягнення кінцевої мети, і забезпечить ефективне проведення оборонної реформи.

Отже, оптимізація формування й раціональне виконання оборонного бюджету на утримання збройних сил можливі на основі стабільного розвитку економіки та раціонального індикативного планування їх розміру. До того ж слід орієнтуватися на оптимальні потреби ЗС України та підвищення їхньої боєздатності. Помилково розраховувати, що в умовах скорочення відрахувань на будівництво ЗС можливо здійснити їх необхідне реформування без докорінної перебудови бюджетної політики i створення потрібного оборонного бюджету. На теперішній час фінансове забезпечення 3С стало вирішальною ланкою всієї воєнної політики держави. Недостатні відрахування коштів є свідченням того, що державна воєнна політика неефективна, не забезпечує зростання боєздатності, перешкоджає розбудові оптимального оборонного комплексу. 3 воєнно-стратегічного погляду нинішня воєнно-фінансова політика держави стосовно збройних сил - небезпечна, не сприяє зміцненню іï суверенітету i незалежності.

Цю проблему потрібно розв'язувати на рівні встановлених причин, а не боротися 3 наслідками, знищуючи безповоротно i так обмежені ресурси. Сучасна система планування суттєво викривлена і відірвана від реалій. Навіть річні плани не виконуються, не кажучи вже про середньо- та довгострокові. $\mathrm{He}$ створено ефективно функціонуючої системи організації: функціонують розірвані між собою окремі iіi елементи, але єдиної складної багаторівневої системи немає.

Отже, в умовах динамічних глобальних геополітичних змін і перетворень у національній економіці, політичній та соціальній сферах розвиток ЗС України потребує уточнення стратегічних пріоритетів оборонної політики, які мають відповідати сучасним викликам і загрозам, вписуватися в систему міжнародної та регіональної безпеки.

\section{СПИСОК ВИКОРИСТАНОЇ ЛІТЕРАТУРИ}

1. Бюджетнй кодекс України. URL: https://zakon.rada.gov.ua/laws/show/2456-17 (дата звернення: 07.11.2019).

2. Про Державний бюджет України на 2019 рік : Закон України. URL: https://zakon.rada.gov.ua/laws/show/262919 (дата звернення: 07.11.2019).

3. Про Державний бюджет України на 2020 рік : проєкт Закону України від 15.09.2019 p. № 2000. URL: http://search.ligazakon.ua/l_doc2.nsf/link1/JI00486A.html (дата звернення: 08.11.2019).

4. Про національну безпеку України : Закон України. URL: https://zakon.rada.gov.ua/laws/show/2469-19 (дата звернення: 08.11.2019).

5. Про Збройні Сили України : Закон України. URL: https://zakon.rada.gov.ua/laws/show/1934-12 (дата звернення: 08.11.2019).

6. Про оборону України : Закон України. URL: https://zakon.rada.gov.ua/laws/show/1932-12 (дата звернення: 08.11.2019).

7. Про рішення Ради національної безпеки і оборони України від 25 квітня 2019 року “Про пропозиції до Бюджетної декларації на 2020 - 2022 роки за статтями, пов'язаними із забезпеченням національної безпеки i оборони України" : Указ Президента України від 
25.04.2019 p. №167/2019. URL: http://www.rnbo.gov.ua/ documents/499.html (дата звернення: 03.11.2019).

$\begin{array}{llll}\text { 8. Військовий } & \text { бюджет } & \text { України. } & \text { URL: } \\ \text { https://uk.wikipedia.org/wiki } & \text { (дата } & \text { звернення: }\end{array}$ 03.11.2019).

9. Вітвіцький Р. А. Актуальні питання фінансового забезпечення Збройних Сил України в особливий період. Актуальні питання готовності підприємств, установ, організацій та військових частин забезпечення життедіяльності Збройних Сил Украӥни до виконання завдань за призначенням в мирний час та в особливий період. Проблеми та можливі шляхи їх вирішення : матеріали наук.-практ. конф. Київ, 2016. C. $83-87$.

10. Левчук О. В. Проблеми фінансового забезпечення розвитку Збройних Сил України. Актуальні питання готовності підприємств, установ, організацій та військових частин забезпечення життєдіяльності Збройних Сил України до виконання завдань за призначенням в мирний час та в особливий період.
Проблеми та можливі шляхи їх вирішення : матеріали наук.-практ. конф. Київ, 2016. С. 87-90.

11. Марко I. Ю., Марко С. I., Чернишова I. М. Зарубіжний досвід забезпечення соціальних гарантій військовослужбовців / Збірник наукових працьь Центру воєнно-стратегічних досліджень Національного університету оборони Украӥни імені Івана Черняховського. Київ, 2019. № 2 (66).

12. Мунтіян В. I. Оборонний бюджет i адекватне фінансування. Рада Національної безпеки і оборони України. 2007. С.118-120.

13. Небава M. I. Tеорія макроекономіки. URL: https://web.posibnyky.vntu.edu.ua/fmib/14nebava_teoriya _makroekonomiki/25.htm (дата звернення: 03.11.2019).

14. Павленко А. М. Економічні чинники впливу на реформування Збройних Сил. Рада Національної безпеки і оборони України. 2008. С.121-126.

15. Плахута В. Бюджет Міноборони 2020. URL: https://defence-ua.com (дата звернення: 03.11.2019).

Стаття надійшла до редакційної колегії 17.12.2019

\section{Financial support of the Armed Forces of Ukraine: trends and ways of reforming}

\section{Annotation}

In the conditions of the development of the Ukrainian council, the issue of ensuring security and defense as a sovereign, independent state, which has taken the path of forming a democratic state system and is an active participant in the processes of Euro-Atlantic integration is particularly acute. At the same time, the Armed Forces of Ukraine and other elements of the security and defense sector play an important role as a guarantor of the effective implementation of foreign policy goals of the state, as well as domestic reforms of public administration. The effective organization and functioning of the Armed Forces and other military formations as the main subjects of ensuring national security and defense is one of the fundamental factors of the effective mechanism of state governance and depends on several diverse indicators. The main indicators are military security, economic security, political stability, information security, and military power.

The defense capability of the Armed Forces of Ukraine fully depends on the level of socio-economic development of the state. At the same time, the security of the country and its economic growth is inextricably linked to the state and possibilities of using economic and military potential. Ensuring the military security of a state is impossible without sufficient financing of its needs while protecting the country from internal and external threats and protecting its national economy without the use of military force (Armed Forces). Therefore, it is necessary to distinguish such a category as the military and economic component of the system of state preparation for defense.

The military and economic component of the system of preparation of the state for defense should be considered as the main, basic part of the general system of national security of the state, which determines the relevance of the chosen research topic.

At the current stage of state development, it is advisable to identify the concept and define the boundaries of the military and economic component of the system of state preparation for defense. This category should be considered not in the system of economic or military security, but as an integrated element in national security. That is, the military and economic component of the system of preparation of the state for defense can be represented as the ability of the military economy to maintain the military power of the country and realization of its military and economic potential in the volumes and terms stipulated in the guiding documents of the state. The military and economic component of the system of preparation of the state for defense represents such a state of the national economy of the country, which ensures sufficient development and preservation of the scientific and production potential of the military economy, which provides material and technical equipment of the armed forces.

Keywords: financing; defense expenditures; military-economic component of the system of preparation of the state for defense; financing of needs of the Armed Forces of Ukraine; defense budget of the country; defense economy; arms and military equipment. 